\title{
Assessing quality of maternity care in Hungary: expert validation and testing of the mother-centered prenatal care (MCPC) survey instrument
}

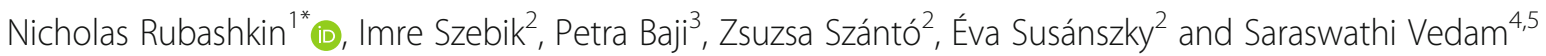

\begin{abstract}
Background: Instruments to assess quality of maternity care in Central and Eastern European (CEE) region are scarce, despite reports of poor doctor-patient communication, non-evidence-based care, and informal cash payments. We validated and tested an online questionnaire to study maternity care experiences among Hungarian women.

Methods: Following literature review, we collated validated items and scales from two previous English-language surveys and adapted them to the Hungarian context. An expert panel assessed items for clarity and relevance on a 4-point ordinal scale. We calculated item-level Content Validation Index (CVI) scores. We designed 9 new items concerning informal cash payments, as well as 7 new "model of care" categories based on mode of payment. The final questionnaire ( $N=111$ items) was tested in two samples of Hungarian women, representative $(N=600)$ and convenience $(N=657)$. We conducted bivariate analysis and thematic analysis of open-ended responses.

Results: Experts rated pre-existing English-language items as clear and relevant to Hungarian women's maternity care experiences with an average CVI for included questions of 0.97. Significant differences emerged across the model of care categories in terms of informal payments, informed consent practices, and women's perceptions of autonomy. Thematic analysis $(N=1015)$ of women's responses identified 13 priority areas of the maternity care experience, 9 of which were addressed by the questionnaire.
\end{abstract}

Conclusions: We developed and validated a comprehensive questionnaire that can be used to evaluate respectful maternity care, evidence-based practice, and informal cash payments in CEE region and beyond.

Keywords: Questionnaire, Validation, Respectful maternity care, Informal payments, Hungary

\section{Plain English summary}

Women in Hungary and in the CEE region report negative experiences with pregnancy care. It is unknown how common these experiences are. High numbers of women pay their obstetricians with informal cash payments, sometimes called "tips", in order to obtain higher quality care. We don't know if, when women pay informally, they actually get higher quality care.

\footnotetext{
* Correspondence: nicholas.rubashkin@ucsf.edu

'Departments of Global Health Sciences and Obstetrics, Gynecology, and Reproductive Sciences, University of California at San Francisco, Mission Hall, Box 1224, 550 16th Street, Third Floor, San Francisco, California 94158, USA Full list of author information is available at the end of the article
}

In order to quantitatively explore the experience of quality maternity care in Hungary, we assembled a multidisciplinary expert panel to adapt English-language maternity care surveys to the Hungarian context. We instructed the experts to think broadly about all aspects of care that may be important to women.

Generally, the experts found that English-language surveys could be easily adapted, and they helped us narrow the number of survey questions from 155 to 117 . Because the informal payment, or "tip" system, is specific to Hungary, the experts developed new questions using Hungarian words to represent this practice. We then tested all questions on two groups of post-partum Hungarian women who use the internet: a random, representative 
sample and another group recruited from online maternity care forums.

We found that the new questions about informal cash payments made sense to women and that women reported more positive experiences with care when they paid informally. Women's responses to an open-ended question revealed that we addressed the majority of care dimensions that mattered to them.

In conclusion, we developed a survey to comprehensively explore the maternity care experience in Hungary. Our survey process and questions may be useful to explore the maternity systems of surrounding countries.

\section{Article summary Strengths}

We used a rigorous process to develop and validate a patient survey instrument that can evaluate women's experiences in the Hungarian maternity care system.

No other survey has explored the connection between informal cash payments and quality of maternity care in the CEE region.

\section{Limitations}

Survey development could have employed more active users of the maternity system. Some care dimensions important to women were not addressed by the survey.

\section{Background}

Person-centered care has been associated with engendering the most optimal relationship between patient and provider in all medical specialties [1]. Balanced sharing of information, individualized care plans, and continuous emotional support are elements that have been shown to improve birth care outcomes and increase satisfaction with the birth experience $[2,3]$. The World Health Organization's (WHO) vision for quality of care for pregnant women and newborns mandates both the provision of evidence-based medical services and curation of the maternal experience $[4,5]$. However, in a systematic review of 65 studies across 34 countries Bohren and colleagues confirmed that few tools exist to measure the experience of respect or mistreatment in maternity care [6].

While the CEE region demonstrates generally favorable maternal health indicators [7], Miteniece et al.'s systematic review of 20 investigations into the region's quality of maternity care confirmed the need to also assess the professional, technical, and informational aspects of maternity care [8]. Birth care providers are often trained with outdated curricula [9], resulting in overapplication of non-evidence-based techniques. Doctor-patient communication is often poor, with providers lacking the skills to interpret what mothers need during pregnancy care $[10,11]$. Women themselves play an important role in the doctor-patient interaction during pregnancy, including uptake of information, optimizing health behaviors, and adherence to care. However, there is scarce information about whether women in the CEE region have autonomy over their childbearing experiences. Mitenice et al. conclude that the evidence on these and other aspects of quality maternity care in the CEE region are derived in large part from qualitative designs, and few studies provide nationally representative data [8].

To date, there have been conflicting quantitative investigations of the quality of maternity care in Hungary. In a 1998 survey of academic obstetric departments, Hagymasy found high levels of "family-centered obstetrics", defined as involvement of fathers, an upright birthing position, and skin-to-skin to contact [12]. In contrast, a 2004 "birth guide", compiled by surveying a convenience sample of women and hospital staff, revealed significant variations in the quality of information provided to pregnant women and in respectful treatment from staff [13].

Neither of these previous surveys explored the effects of informal cash payments, even though in Hungary more than $60 \%$ of pregnant women pay informally for birth care [14]. Informal and formal cash payments may affect quality of maternity care in terms of affordability and accessibility of services. As with fee-for-service official payment schemes, informal payments may generate unnecessary use of services with "doctors recommending procedures in order to increase their income rather than for therapeutic benefit $[15,16]$." Even though quantitative data is lacking, qualitative studies from Serbia and the Ukraine found that women pay informally to have a "chosen" obstetrician attend their births, and that they perceive many benefits to this continuity relationship-mainly, receiving more respectful care $[10,17]$. However, given the lack of representative data to measure and monitor the quality of maternity care, the extent to which women actually benefit from these payments is unknown.

Investigators in the United States and in Canada have used cross-sectional surveys to assess women's experiences of quality maternity care, addressing issues of evidence-based care, doctor-patient communication, and the process of decision-making in birth. The American survey Listening to Mothers 3 (LTM3) has been administered three times to a representative cohort of U.S. women [18]. Changing Childbirth in British Columbia (CCinBC) incorporated items from LTM3 but also used community-based participatory research methods to develop new items pertaining to women's maternity care preferences, their decision-making, and perceptions of autonomy and respect $[19,20]$. Given the existence of high-quality, English-language survey items, we decided to adapt and content validate these items for use in the 
Hungarian context with the primary aim of creating a comprehensive questionnaire to explore quality maternity care. Specifically, we examined quality care according to the rates of obstetric procedures, several measures of the experience of care, as well as the prevalence of informal cash payments.

\section{Methods}

\section{Survey construction}

To create the first version of the questionnaire, we combined the LTM3 and the CCinBC surveys. Duplicate items and those specific to foreign systems (e.g., American health insurance) were excluded. We added a validated scale to measure women's role and ability to participate in decision-making, the Mothers Autonomy in Decision Making scale (MADM) developed by Vedam and colleagues [19]. We adapted informal payment questions from a cross-country survey on general inpatients [21].

The Hungarian maternity care system has similarities to Canada and the United States. A national health insurance scheme covers Hungarian maternity services (as in Canada), and a Hungarian woman has her choice of private or public prenatal providers (as in Canada and the U.S.). Like North America, providers are not required to be present for the births of their prenatal patients, in which case the "on-call" provider attends the birth. Unlike North America, in Hungary a pregnant woman who desires to have her "chosen" prenatal provider present at her birth will informally "contract" with her physician for the "extra" service of attending the birth [22].

Informal cash payments pose several challenges to quantitative exploration. First, informal cash payments are usually unregistered, and no government data source exists [23]. Second, Stepurko et al. found that respondents frequently refuse to answer questions about informal payments [24]. Finally, a woman typically pays after her delivery, making it challenging to explore associations with prenatal and birth outcomes that necessarily happen prior to the payment [17]. Thus, we needed to develop survey items that would be both culturally acceptable and-at least in concept-precede in time the outcomes of interest.

\section{Content validation}

When designing instruments it is common to undertake a validation process to provide evidence that the instrument is relevant to the regional context. One approach is to have experts judge the relationship between the survey items and the theory on which the instrument is based $[25,26]$. We invited 31 lay and professional maternity care content experts-including active users of the system - to validate the comprehensiveness and regional specificity of our questionnaire [27]. Experts were identified through purposive sampling of research, professional, and birth-advocacy networks to maximize non-overlapping expertise [28]. Those experts who accepted our invitation were instructed on how to review the survey items in light of the concept of "women-centered care", focusing on issues of continuity of care, doctor-patient communication, care preferences, and the use of evidence-based techniques [3, 29]. We required all experts to be bilingual in English and Hungarian.

The final survey instrument, "The Mother-Centered Pregnancy Care Survey", consisted of 111 items: 5 screening, 16 prenatal care, 35 birth care, 12 postpartum care, 22 care preferences, 11 informal payments, 8 MADM scale items, 2 open-ended questions that inquired about the best and worst aspects of the experience of care. Among these, a total of 75 questions collected information on elements of women-centered care and were woven across the above domains.

The final questionnaire then underwent 5-way independent translation, as has been first previously used in Hungarian research, consisting of 3 independent translators who worked in parallel, followed by 1 translator who reconciled and assembled these parallel versions, and concluded by 1 final back translation of the reconciled Hungarian version into English [30]. The final back translation was checked for accuracy by an author who is a native English speaker (NR). Four Hungarian maternity care users beta-tested the survey for language, length, clarity, and functionality.

\section{Survey administration}

With the help of mostly international private donors without vested interests, a sum of $\$ 4300$ US dollars was raised to retain the survey firm Ipsos. Ipsos maintains a panel of more than 70,000 members who are representative of Hungarian internet users for age, sex, and geographical location. We selected women between the ages of 18-45 with children under the age of 5 as the "target" population (total available $N=7762$ ).

\section{Sample}

Ipsos administered the survey to the target population using a quota system to ensure a representative distribution regarding age, marital status, household size, education level, monthly income, settlement, and marital status. Balancing the resources available with the sample size needed to conduct a robust analysis, Ipsos stopped the invitations once a representative sample of 600 women was achieved. Ipsos also managed data collection for a convenience sample $(N=657)$ obtained via social media networks of birth and parenting organizations. Recruitment lasted for the month of October 2014. All 


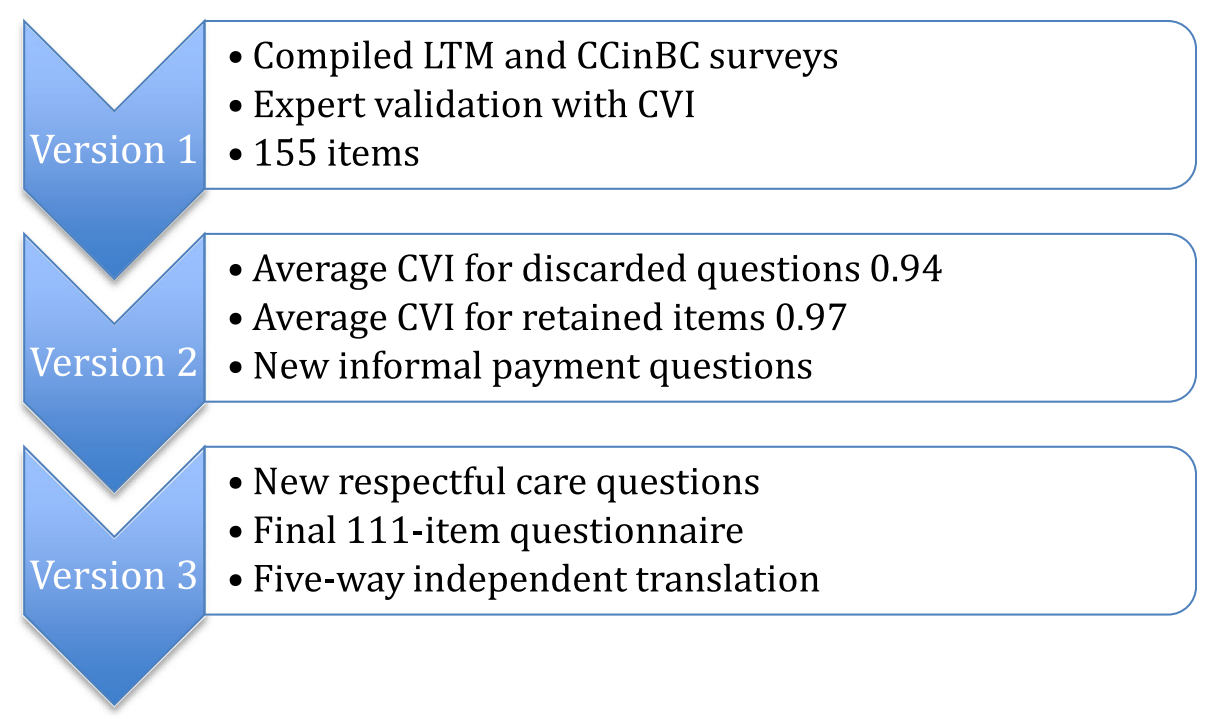

Fig. 1 Survey development process

respondents gave informed consent prior to initiating the survey.

\section{Analysis}

The research team reviewed all numeric and qualitative data supplied by the expert panel. We assessed interrater agreement by using the content validity index (CVI), summing the number of experts who rated an item as highly relevant and clear (level 3 or 4 ) and dividing by the total experts. We then averaged these scores to generate an item-level CVI (I-CVI). We considered items to be relevant and clear with an I-CVI score greater than 0.8 [26]. We reviewed all comments with equal attention, giving extra weight to repeat themes. Revisions were done carefully in dialogue between a native English speaker (NR) and a native Hungarian speaker (IS) in order to maintain clarity.

We compared demographic characteristics with twotailed $\mathrm{z}$ tests (for dummy variables) or Pearson $\mathrm{Chi}^{2}$ test (for categorical variables). We then compared the amount of informal payments across groups by twotailed $\mathrm{t}$ or $\mathrm{z}$ tests (ANOVA). We employed STATA version 14.1 for all statistical calculations. Responses to an open-ended question "What was the worst thing about the care you received during your recent birth?" underwent thematic analysis [31]. Two authors (ZS and ES) read through all the responses, categorized the content, and then coded the content by hand in order to determine the frequency of different themes.

The Regional Ethics Committee of Semmelweis University, Budapest (ref. number: 99/2014) approved this study. Because participation in the study was voluntary and preserved the anonymity of the participants with no invasive sampling techniques, the ethics committee did not require a formal consent process. Nonetheless, the survey opened with a discussion of risks, benefits, and potential harms, and then stated that by starting the survey a woman consented to participate. Our research was conducted in full accordance with the World Medical Association Declaration of Helsinki.

\section{Results}

Eleven of the 31 invited multi-disciplinary experts completed the entire validation process. The final panel consisted of: research and a clinical psychologists [2]; obstetrician-gynecologists [2]; a lawyer expert in birth issues [1]; directors of non-governmental organizations [2]; a midwife [1]; a doula [1]; an epidemiologist [1]; a mother [1]. One of the psychologists runs a support group for new mothers, and the NGO directors lead initiatives on expanding pregnancy and birth options. The doula herself is a mother and has supported birthing mothers in Hungary. Thus, 6 of the 11 experts had personal experiences as, or close relationships with active users of Hungarian maternity care.

Figure 1 summarizes the survey development and validation process. Only 3 items scored below the commonly used I-CVI cut off at or below 0.8. The LTM3 question "Is your baby during this time period living?" received an I-CVI of 0.8. Experts felt this question used harsh language and might turn women away. Another question from LTM3, "Did you get your first prenatal visit as early in your pregnancy as you wanted?" scored 0.76; experts felt this question was not relevant to a socialized health system. As a group the informal payment questions received scores (I-CVI 0.93) above the cut off for inclusion. However, experts consistently commented on the lack of relevance to the intrapartum context of 
Table 1 Nine new informal cash payment questions

Considering all types of official and informal cash payments, how much IN TOTAL did you spend (out of pocket, in cash) related just to the delivery of your baby? This refers to the amount of cash paid after your prenatal visits concluded.

a. Total amount

b. I don't remember

c. Decline to answer

How much of this [X amount paid] for your birth was an informal cash payment?

a. Total amount

b. I don't remember

c. Decline to answer

When you paid cash for your pregnancy and birth care-in the private or the public system-what did you expect to receive in return? Choose all that apply.

I expected to...Yes/No (Select all that apply instead of Yes/No)

a. Receive better quality care

b. Obtain more attention from the staff

c. Find a more skilled physician and/or midwife

d. Wait less time to get an appointment

e. Have better access to my doctor and/or midwife

f. Have my chosen doctor or midwife attend my birth

g. Have more control over my care

h. Because I felt thankful for care I received.

i. Get nothing in return. I felt is was required to pay.

j. Other [text box]

When did you make the informal cash payment for your delivery?

a. Before I gave birth

b. After I gave birth while I was in the hospital

c. After I gave birth and went for a visit to the clinic

d. I don't remember

You spent $[x$ amount] for all of your prenatal visits and birth care, forma and informal. Was it necessary to borrow cash from family or friends, the bank or from a credit card, or sell personal assets to cover this cost?

a. Yes

b. No

c. I don't remember
Beleértve az összes hivatalos dijat és nem hivatalos hálapénzt, mennyi pénzt fizetett Ön (és családja) összesen a szülésért a saját zsebéből, készpénzben? Ebbe az összegbe ne számítsa bele a szülést megelőző vizitek árát akkor sem, ha a befizetett összeg után nem kapott számlát! a. Teljes összeg: ezer FORINT

b. Nem emlékszem.

c. Nem kívánok válaszolni.

Ebből az összegből a hálapénz összege:

a. ezer FORINT

b. Nem emlékszem.

c. Nem kívánok válaszolni.

Amikor hálapénzt fizetett a szülésért mit várt el a pénzéért cserébe? Több választ is bejelölhet. "Igen"-nel és "Nem"-mel felelhet.

Azt vártam, hogy...

a. jobb minőségú ellátást kapjak.

b. több figyelmet kapjak a személyzettől.

c. jobb orvost és/vagy szülésznőt kapjak.

d. kevesebbet kelljen várnom arra, hogy időpontot kapjak.

e. jobb hozzáférésem legyen az orvosomhoz és/vagy szülésznőmhöz.

f. a választott orvosom vagy szülésznőm legyen jelen a szülésemnél.

g. legyen beleszólásom az ellátásomba.

h. Azért fizettem, mert hálás voltam az ellátásért, amit kaptam.

i. Nem vártam semmit viszonzásképpen. Muszáj volt fizetnem.

j. Egyéb: a fentiektől eltérő dolgot vártam:

Mikor fizetett Ön hálapénzt a szüléséért?

a. A szülés előtt.

b. A szülés után, amíg még a kórházban voltam.

c. A szülés után, amikor vizsgálatra/ellenőrzésre mentem.

d. Nem emlékszem.

Ön összesen (beleértve a hivatalos összegeket és a hálapénzt is) forintot költött a várandósgondozásra és a szülésre. Kellett ehhez kölcsönkérnie pénzt családtagoktól vagy barátoktól, esetleg banki kölcsönt felvennie vagy hitelkártyán túlköltenie, vagy eladni valamilyen személyes tárgyat/ tulajdont, hogy ki tudja fizetni ezt az összeget?

a. Igen.

b. Nem.

c. Nem emlékszem.

You paid an informal payment during your prenatal care or for your birth Did your provider ask you to pay a specific amount, or did they leave it up to you to decide how much to pay?

a. Yes, they asked for a specific amount.

b. No, they let me decide how much to pay.

c. I don't remember

You paid $[\mathrm{x}]$ amount in total for informal cash payments during your prenatal care and birth. To whom did you make this informal cash payments? Choose all that apply.

a. A doctor in the clinic

b. A nurse in the clinic

c. A doctor in the hospital

d. A nurse in the hospital

e. A midwife in the hospital

f. A midwife at home

g. Other

h. I don't remember

You said that you paid [ $x$ amount] in informal cash payments for your pregnancy and birth care. How did you feel about this informal cash payment?

Very negative/ Somewhat negative/ Indifferent/ Somewhat positive/ Very positive

During your recent birth while in the hospital or at home, how often were you treated poorly because of...? Check all that apply. a. Your race, ethnicity, cultural background or language spoken b. Your financial situation
Amennyiben fizetett hálapénzt a várandósgondozás alatt és a szülésért, kérte Öntől az szülészeti ellátója, hogy fizessen egy bizonyos összeget vagy Önre bízta, hogy mennyit fizet?

a. Igen, kértek egy bizonyos összeget.

b. Nem, rám bízták, hogy mennyit fizetek.

c. Nem emlékszem

Ön ezer forint hálapénzt fizetett a várandósgondozásért és a szülésért. Kinek adta ezt a hálapénzt? Jelölje be azokat a személyeket, akinek adott pénzt! Több személyt is megjelölhet.

a. Egy orvosnak a rendelöben.

c. Egy orvosnak a kórházban.

d. Egy nővérnek a kórházban.

e. Egy szülésznőnek a kórházban.

f. Egy otthonszülést kísérő bábának.

g. Másnak

h. Nem emlékszem.

Amennyiben fizetett hálapénzt a várandósgondozás alatt és a szülésért, hogyan érintette Önt, hogy fizetnie kellett?

Nagyon rosszul érintett / Kicsit rosszul érintett / Közömbösen /

Meglehetősen pozitívan érintett / Nagyon pozitívan érintett

A legutóbbi vajúdásánál és szülésénél - akár kórházban zajlott, akár otthon - milyen gyakran bántak Önnel igazságtalanul az alábbi okokból? Jelölje meg az összeset, amely igaz. Több választ is bejelölhet. b. Egy nővérnek a rendelőben. 
Table 1 Nine new informal cash payment questions (Continued)

c. Your sexual orientation or gender identity

d. You refused care that your provider recommended

e. Because you developed a birth plan

f. Because you did not pay an informal cash payment

Never/ Sometimes/ Usually/ Always a. Az Ön bőrszíne, nemzetiségi hovatartozása, kultúrális háttere, anyanyelve miatt?

b. Az Ön anyagi helyzete miatt?

c. Az Ön szexuális orientációja vagy nemi identitása miattt?

d. Azért, mert Ön visszautasította a szülészeti ellátója javaslatait?

e. Azért, mert Ön szülési tervvel érkezett?

f. Azért, mert Ön nem adott hálapénzt?

Soha/néha/általában/mindig questions developed for general inpatients. Table 1 lists the nine new informal payment questions that we developed with expert input.

After the informal payment questions the next most challenging group of items referred to the overlap between payments and the model of care (doctor, midwife). Experts decided that the process of paying a provider informally hinged on the model that the majority of women select prior to delivery. In accordance with previous research and their own system knowledge, experts then decided to use the word "chosen" (választott) to refer to the continuity prenatal relationship that women pay for informally. The word "chosen" was then applied to the private and public models of care to yield three models of chosen doctor care and one model of chosen (hospital) midwifery care. Two models of "not chosen" care represented the default model provided by the state insurance system. Independent home birth midwifery was its own category. These linguistic results are shown in Table 2.

Ipsos field tested the survey and confirmed that the duration of participant engagement required approximately $30 \mathrm{~min}$. Altogether, Ipsos sent $892 \mathrm{e}$-mail invitations to their panel with a response rate of $67 \%$. Reasons for drop out were: 14 (1.6\%) quota full, 115 (12.9\%) screened out, 163 (18.3\%) terminated the survey. In addition, 657 completed surveys were obtained through convenience internet sampling. Table 3 shows demographic indicators for the sample with the corresponding most recent census data listed below the table. Overall, the representative sample compared well to recent census data. Pearson $\mathrm{Chi}^{2}$ statistics show that the convenience sample was statistically significantly more highly educated women $\left(\mathrm{Chi}^{2}=341.8, p<0.0001\right)$, lived in the capital $\left(\mathrm{Chi}^{2}=128.2, p<0.0001\right)$, and had higher average net incomes $(t=-16.02, p<0.0001)$.

Table 4 reveals the informal payment practices in the representative sample according to the model of care categories. Excluding the categories with fewer than five respondents, we see that the response percentages to the informal payment question ranged between 75 and $86 \%$. Pearson $\mathrm{Chi}^{2}$ statistics showed that the share of women who paid informally was significantly different across the groups $\left(\mathrm{Chi}^{2}=183.6 ; p<0.0001\right)$. ANOVA test shows that the amount of informal payment is also significantly different across groups $(\mathrm{F}=6.73, p<0.0001)$.

Regarding informed consent practices, Table 5 shows the responses from the representative sample as to whether a woman's permission was obtained prior to undergoing a cesarean $(N=244)$ or an episiotomy $(N=$ 257). Pearson $\mathrm{Chi}^{2}$ statistics showed that the permission practices were significantly different across provider types for cesarean section $\left(\mathrm{Chi}^{2}=39.2, p=0.003\right)$ but were not significantly different for episiotomy $\left(\mathrm{Chi}^{2}=18.6, p=\right.$ $0.414)$. MADM scores were significantly different across permission categories (ANOVA results for caesarean: $\mathrm{F}=$ $14.50, p<0.0001$, for episiotomy: $\mathrm{F}=10.34 p<0.0001)$.

Table 6 shows the coded results from an open-ended question from LTM3. Thematic analysis of the openended responses $(N=1015)$ from the entire sample identified 13 priority areas of the maternity care experience, 9 of which were addressed by the questionnaire.

Table 2 Model of care categories with linguistic results

\begin{tabular}{|c|c|c|c|}
\hline $\begin{array}{l}\text { Which of these providers was the most important } \\
\text { source of your prenatal care? }\end{array}$ & $\begin{array}{l}\text { Hungarian linguistic adaptation of model of care } \\
\text { categories }\end{array}$ & $\begin{array}{l}\text { Convenience N } \\
=657(\%)\end{array}$ & $\begin{array}{l}\text { Representative N } \\
=600(\%)\end{array}$ \\
\hline Chosen doctor in a private hospital system & választott orvos magánkórházban & $10(1.5)$ & $2(0.3)$ \\
\hline Chosen doctor in a private practice & választott orvos magánrendelésen & $287(43.8)$ & $167(28.0)$ \\
\hline Chosen doctor in a state institute & választott orvos állami intézményben & $119(18.1)$ & $184(30.8)$ \\
\hline Chosen hospital midwife & választott (kórházi) szülésznő & $78(11.9)$ & $28(4.7)$ \\
\hline Independent (home birth) midwife & független bába & $82(12.5)$ & $3(0.5)$ \\
\hline $\begin{array}{l}\text { I did not choose a doctor, just went to my local } \\
\text { clinic }\end{array}$ & $\begin{array}{l}\text { nem választottam orvost, a helyi rendelőintézetbe/ } \\
\text { szakrendelőbe jártam }\end{array}$ & $68(10.4)$ & $155(26.0)$ \\
\hline District public health nurse & védőnő & $12(1.8)$ & $58(9.7)$ \\
\hline I did not go to prenatal care & nem jártam várandósgondozásra & 1 & $3(0.5)$ \\
\hline
\end{tabular}


Table 3 Social demographic indicators

\begin{tabular}{|c|c|c|c|}
\hline & & $\begin{array}{l}\text { Convenience } \\
N=657\end{array}$ & $\begin{array}{l}\text { Representative } \\
N=600\end{array}$ \\
\hline Age & $\begin{array}{l}\text { Age in years (SD) } \\
\text { Min, Max }\end{array}$ & $\begin{array}{l}33.7(4.18) \\
20,47\end{array}$ & $\begin{array}{l}33.3(4.96) \\
21,45\end{array}$ \\
\hline \multirow{6}{*}{$\begin{array}{l}\text { Education }{ }^{a} \\
(\%)\end{array}$} & Less than $<7$ grade & 0 & $17(2.8)$ \\
\hline & Grade 8 & 0 & $16(2.7)$ \\
\hline & Trade School & $9(1.3)$ & $92(15.3)$ \\
\hline & High School & $91(13.9)$ & $244(40.7)$ \\
\hline & College & $256(39.0)$ & $167(27.8)$ \\
\hline & University diploma & $301(45.8)$ & $64(10.7)$ \\
\hline \multirow{4}{*}{$\begin{array}{l}\text { Settlement }{ }^{\mathrm{b}} \\
(\%)\end{array}$} & Capital & $304(46.3)$ & $100(16.7)$ \\
\hline & County Seat & $95(14.5)$ & $124(20.7)$ \\
\hline & City & $151(23.0)$ & $200(33.3)$ \\
\hline & Village & $107(16.3)$ & $176(29.3)$ \\
\hline \multirow{3}{*}{$\begin{array}{l}\text { Net } \\
\text { Income } \\
\text { (thousands HUF) }\end{array}$} & Mean (SD) & $374(218)$ & $209.23(118)$ \\
\hline & Max & 2250 & 875 \\
\hline & Missing & & $39(6.5)$ \\
\hline
\end{tabular}

${ }^{a}$ Census data education, women age 20-49: Less than high school 19.6\%; completed high school 39.5\%; college degree and above $26.1 \%$

${ }^{\mathrm{b}}$ Census data settlement, entire population: Capital $17.4 \%$; County seat $20.4 \%$; city $31.7 \%$; village $30.5 \%$

'Census data income, net household 2014: average 158 thousands of forints

\section{Discussion}

We used a standardized and rigorous methodology to develop and validate a survey instrument that comprehensively examined maternity care experiences in Hungary, thus filling an important gap where no governmentsponsored data exists. The process included collating validated items from the international literature, adapting them to the Hungarian context by expert panel, designing region-specific new items, and validating the content. To the best of our knowledge, no other group has undertaken this task. We found that existing English-language survey items concerning the experience of maternity care were clear and relevant to the Hungarian context. This is likely due to the fact that many of the issues related to excessive obstetric procedures, poor communication, and the lack of maternal autonomy that we found in Hungary are also common in the United States and Canada $[8,18,19]$.

Our expert process proved effective at identifying survey domains that required additional adaptation. For example, our maternity care experts identified that informal payment questions developed for general inpatients required adaptation. Our expert panel integrated linguistic, system, and user expertise to develop new survey items specific to the CEE region. We believe this was a result of the collaboration across our diverse panel. Some argue that content experts should have significant research or clinical experience. However, inclusion of "lay" experts has been found to be appropriate in many situations [27] and is consistent with the principles of patient-centered research [32].

To test reliability, we administered the survey to two samples of service users: a randomly selected representative sample and a parallel convenience sample. The instrument performed well in both groups: it was user friendly, feasible to distribute in an online format, and captured information on several domains relevant to maternal experience of care during pregnancy and childbirth.

In our 30 -min survey $67 \%$ of the items addressed issues of person-centered care. We found that the extent of informed consent and autonomy (MADM scores) varied significantly across the model of care categories. We also found lower MADM scores in the women who had cesareans and episiotomies performed without their consent. Lack of consent for procedures was a common theme in the responses to the open-ended question. These findings are discussed in detail in a separate paper [33] and are supported by qualitative studies that show that women pay informally to receive care that they perceive to be more respectful $[10,17]$. Analysis of our model of care categories showed extensive overlap between informal payments and the use of the word "chosen". Women who went to their local clinic without choosing a doctor paid informally $17 \%$ of the time-the lowest frequency of all the models of care. We believe

Table 4 Informal payments by provider type, representative sample

\begin{tabular}{llll}
\hline & $\begin{array}{c}\text { Answered informal payment question, } \\
\text { N }(\%)\end{array}$ & Reported paying informally, & $\begin{array}{c}\text { Av. amount of informal } \\
\text { payment } \\
\text { EUR (SD) }\end{array}$ \\
\hline Chosen doctor in a private hospital system & $2(100)$ & $2(100)$ & $333(236)$ \\
Chosen doctor in a private practice & $125(75)$ & $102(82)$ & $210(128)$ \\
Chosen doctor in a state institute & $138(75)$ & $108(78)$ & $169(103)$ \\
Chosen hospital midwife & $24(86)$ & $22(92)$ & $203(99)$ \\
Independent (home birth) midwife & $3(100)$ & $0(0)$ & - \\
I did not choose a doctor, just went to my local clinic & $125(81)$ & $21(17)$ & $81(45)$ \\
District public health nurse & $50(86)$ & $10(20)$ & $118(65)$ \\
I did not go to prenatal care & $2(67)$ & $0(0)$ & - \\
Total & $469(78)$ & $265(57)$ & $180(116)$ \\
\hline
\end{tabular}


Table 5 Permission for cesarean $(N=244)$ or episiotomy $(N=257)$, representative sample

\begin{tabular}{|c|c|c|c|c|c|c|c|c|}
\hline & \multicolumn{2}{|c|}{$\begin{array}{l}\text { Yes, they asked and I } \\
\text { gave my permission. }\end{array}$} & \multicolumn{2}{|c|}{$\begin{array}{l}\text { No, they did not ask } \\
\text { my permission. }\end{array}$} & \multicolumn{2}{|c|}{$\begin{array}{l}\text { I refused the } \\
\text { procedure, but they } \\
\text { still did it. }\end{array}$} & \multicolumn{2}{|c|}{ I don't remember } \\
\hline & Cesarean & Episiotomy & Cesarean & Episiotomy & Cesarean & Episiotomy & Cesarean & Episiotomy \\
\hline Chosen doctor in a private practice (\%) & $72(91.1)$ & $25(35.2)$ & $5(6.3)$ & $42(59.2)$ & 0 & $1(1.4)$ & $2(2.5)$ & $3(4.2)$ \\
\hline Chosen doctor in a state institute (\%) & $79(90.8)$ & $27(35.5)$ & $6(6)$. & $45(59.2)$ & 0 & 0 & $2(2.3)$ & $4(5.2)$ \\
\hline $\begin{array}{l}\text { Chosen hospital midwife in a private or state } \\
\text { clinic (\%) }\end{array}$ & $4(57.1)$ & $7(41.2)$ & $2(28.6)$ & $9(52.9)$ & 0 & 0 & $1(14.3)$ & $1(5.9)$ \\
\hline $\begin{array}{l}\text { I did not choose a doctor, just went to my local } \\
\text { clinic (\%) }\end{array}$ & $37(72.6)$ & $16(24.2)$ & $9(17.7)$ & $46(69.7)$ & $1(2.00)$ & $1(1.5)$ & $4(7.8)$ & $3(4.6)$ \\
\hline District public health nurse (\%) & $14(70.0)$ & $8(29.6)$ & $6(30.0)$ & $18(66.7)$ & 0 & 0 & 0 & $1(3.7)$ \\
\hline Total (\%) & $206(84.5)$ & $83(32.6)$ & $28(11.4)$ & $160(62.0)$ & $1(0.4)$ & $2(0.8)$ & $9(3.7)$ & $12(4.7)$ \\
\hline MADM score Mean (SD) & $26.9(7.5)$ & $28.1(6.5)$ & $19.0(5.7)$ & $22.3(8.3)$ & - & $23.5(12.0)$ & $18.4(7.1)$ & $23.7(7.9)$ \\
\hline
\end{tabular}

the statistically significant different distribution of informal payments across the care categories validates these categories for future research in Hungary and the CEE region. Because informal payments may distort health care services in ways that require policy intervention [21], reliable survey items are necessary to evaluate their effects [23].

\section{Limitations}

Because we chose an expert validation process without extensive community involvement, we may not have addressed additional elements of mothercentered care in this population. For example, responses to the open-ended questions indicate additional items could have addressed the physical state of the maternity and newborn wards, newborn care in general, and home birth. Additionally, internet users may not be representative of the Hungarian general population; a more representative sample would require telephone or face-to-face interviewing. Finally, given the challenges of surveying the broad preferences and outcomes of the entire maternity system, ideal distribution of our survey would capture more pathways, especially for ethnic/minority and poor women.

\section{Conclusion}

We developed a reliable and relevant survey instrument to evaluate evidence-based care and maternal experiences in Hungary. This survey instrument can be easily adapted for use in other Central and Eastern European countries, where informal payments, the variable application of evidence, and concerns with respectful provider-patient relationships are similar. We plan to utilize the data resulting from this survey to inform interprofessional education and elucidate

Table 6 Thematic analysis of responses to open-ended question: What was the worst thing about the care you received during your recent birth? $(N=1015)$

\begin{tabular}{ll}
\hline & Explored by any items in the final survey \\
\hline 1. No consent for interventions / interventions done against my wishes & Yes \\
2. Painful interventions (vaginal examinations, cervix stretching, episiotomy) & Yes \\
3. Doctor/midwife style & Yes \\
4. Hurrying the labor & Yes \\
5. I could not choose a comfortable position & Yes \\
6. They did not help with breastfeeding & Yes \\
7. Lacking information & Yes \\
8. Did not allow support people to be present & Yes \\
9. Problems with prenatal care & Yes \\
10. Hospital condition (room, bed, food, bathroom) & No \\
11. Newborn hospital unit & No \\
12. Children could not be with me & No \\
13. Told home birth was too dangerous & No \\
\hline
\end{tabular}


determinants of high quality maternity care in Hungary. A survey similar to ours could be used to regularly monitor trends in Hungarian maternity care as well as for cross-country comparisons in the CEE region, where representative data on quality maternity care is lacking.

\section{Abbreviations}

CCinBC: Changing Childbirth in British Columbia; CEE Region: Central and Eastern European Region; CVI: Content Validity Index; LTM3: Listening to Mothers 3; MADM: Mothers Autonomy in birth Decision Making scale

\section{Acknowledgements}

We would like to acknowledge our expert panel and translators, without whom this research would not have been possible: Experts: Balazs Balint, Agnes Czovek, Agnes Geréb, Nora Schimcsig, Katalin Varga, Erika Schmidt, Stefania Kapronczay, Linda Roszik, Peter Lobmayer, Anna Iványi, Zuzana Kriskova. Translators: János Hanák; Frigyes Tarján, Erika Solyom, Zsofia Goreczky. Pilot testers: Anna Ternovszky, Zsuzsana Kertesz, Irén Móré and Klára Ecsedi.

\section{Funding}

Funding for data collection was obtained through "crowd sourcing" via the internet website Crowdrise.com. A proposal was posted on the website, and individual private donors contributed funds. To mitigate conflict of interest, we asked that no women who planned to participate in the study contribute to the fund. These privately raised funds were used to retain the survey firm Ipsos (Thaly Kalman utca 39, Budapest Hungary). Petra Baji's research was supported by the Hungarian Scientific Research Fund OTKA (PD 112499). Nicholas Rubashkin's research was supported by a Fulbright research scholar grant.

\section{Open access}

The authors agree to make the supporting data available.

\section{Authors' contributions}

NR and IS were co-investigators during the entire survey validation and analysis process. Dr. R drafted this paper and thus is first author. PB contributed an economic perspective with survey items concerning informal payments and analysis of the informal payments. She also conducted statistical tests for the data contained herein. ZS and ÉS consulted on survey sampling techniques and conducted the thematic analysis of the responses to one of the open-ended questions. SV performed the role of supervising researcher, working closely with $\mathrm{Dr}$. R throughout the entire survey validation and analysis process. She also edited drafts and approved the final manuscript. All authors read and approved the final manuscript.

\section{Ethics approval and consent to participate}

The Regional Ethics Committee of Semmelweis University, Budapest (ref. number: 99/2014) approved this study. Because participation in the study was voluntary and preserved the anonymity of the participants with no invasive sampling techniques, the ethics committee did not require a formal consent process. Nonetheless, the survey opened with a discussion of risks, benefits, and potential harms and then stated that by starting the survey a woman consented to participate. Our research was conducted in full accordance with the World Medical Association Declaration of Helsinki.

\section{Consent for publication}

All authors consent to this article's publication.

\section{Competing interests}

The authors alone are responsible for the content and writing of this paper. We declare no financial, political, intellectual, or religious interests in this research.

\section{Publisher's Note}

Springer Nature remains neutral with regard to jurisdictional claims in published maps and institutional affiliations.

\section{Author details}

'Departments of Global Health Sciences and Obstetrics, Gynecology, and Reproductive Sciences, University of California at San Francisco, Mission Hall, Box 1224, 550 16th Street, Third Floor, San Francisco, California 94158, USA. ${ }^{2}$ Institute of Behavioral Sciences, Semmelweis University, VIII. Nagyvárad tér 4. XX. Em, Budapest H-1089, Hungary. ${ }^{3}$ Department of Health Economics, Corvinus University of Budapest, Fővám tér 8. Main Building Room E113, Budapest 1093, Hungary. ${ }^{4}$ The Birth Place Lab, Faculty of Medicine, The University of British Columbia, Vancouver, Canada. ${ }^{5}$ Midwifery Program | Department of Family Practice, Suite 320 - 5950 University Boulevard, Vancouver, BC V6T 1Z3, Canada.

Received: 9 June 2017 Accepted: 10 November 2017 Published online: 16 November 2017

\section{References}

1. Rao JK, Anderson L, Inui T, Frankel RM. Communication interventions make a difference in conversations between physicians and patients: a systematic review of the evidence. Med Care. 2007;45(4):340-9.

2. Hodnett ED, Gates S, Hofmeyr G, Sakala C. Continuous support for women during childbirth. Cochrane Database Syst Rev. 2013;7:CD003766. doi:10. 1002/14651858.CD003766.pub5.

3. lida M, Horiuchi S, Porter SE, Pope R, Graham L, Patel S. The relationship between women-centred care and women's birth experiences: a comparison between birth centres, clinics, and hospitals in Japan. Midwifery. 2012;28(4):398-405.

4. Tuncalp O, Were WM, MacLennan C, Oladapo OT, Gulmezoglu AM, Bahl R, et al. Quality of care for pregnant women and newborns-the WHO vision. BJOG. 2015;122(8):1045-9.

5. Miller S, Lalonde A. The global epidemic of abuse and disrespect during childbirth: history, evidence, interventions, and FIGO's mother-baby friendly birthing facilities initiative. Int J Gynaecol Obstet. Feb 2015;123(2):93-4.

6. Bohren MA, Vogel JP, Hunter EC, Lutsiv O, Makh SK, Souza JP, et al. The mistreatment of women during childbirth in health facilities globally: a mixed-methods systematic review. PLoS Med. 2015;12(6):e1001847. doi:10. 1371/journal.pmed.1001847.

7. Wang $\mathrm{H}$, Liddell CA, Coates MM, Mooney MD, Levitz CE, Schumacher AE, et al. Global, regional, and national levels of neonatal, infant, and under-5 mortality during 1990-2013: a systematic analysis for the global burden of disease study 2013. Lancet. Sep 2014;384(9947):957-79.

8. Miteniece E, Pavlova M, Rechel B, Groot W. Barriers to accessing adequate maternal care in central and eastern European countries: a systematic literature review. Soc Sci Med. 2017;177:1-8.

9. Danichevski K, McKee M, Balabanova D. Prescribing in maternity care in Russia: the legacy of soviet medicine. Health Policy. 2008;85(2):242-51.

10. Arsenijevic J, Pavlova M, Groot W. Shortcomings of maternity care in Serbia. Birth. 2014;41(1):14-25

11. Colombini M, Rechel B, Mayhew SH. Access of Roma to sexual and reproductive health services: qualitative findings from Albania, Bulgaria and Macedonia. Glob Public Health. 2012;7(5):522-34.

12. Hagymasy L, Gaal J. A comparative study of vertical and horizontal deliveries in the presence and with the assistance of the woman's partner. J Psychosom Obstet Gynaecol. 1998;19(2):98-103.

13. Farkasne S, Velkei E. "Birth Guide: About the Hungarian Birth Services" (Születéskalauz: a magyarorszagi szuleszeti intezmenyek szolgaltatasairol). First ed. Budapest: Merce Egyesulet; 2001. 265 p.

14. ASSPRO. The price of a childbirth: out-of-pocket payments for maternity care in central and eastern europe. Maastricht, the Netherlands: Maastricht University; 2013

15. Falkingham J. Poverty, out-of-pocket payments and access to health care: evidence from Tajikistan. Soc Sci Med. 2004;58:247-58.

16. Cohen N. Informal payments for health care-the phenomenon and its context. Health Econ Policy Law. 2012;7(3):285-308.

17. Stepurko T, Pavlova M, Levenets O, Gryga I, Groot W. Informal patient payments in maternity hospitals in Kiev Ukraine. Int J Health Plann Manag. 2013;28(2):169-87

18. Declercq ER, Sakala C, Corry MP, Applebaum S, Herrlich A. Major survey findings of listening to mothers (SM) III: pregnancy and birth: report of the third National U.S. survey of Women's childbearing experiences. J Perinat Educ. 2014;23(1):9-16. 
19. Vedam S, Stoll K, Martin K, Rubashkin N, Partridge S, Thordarson D, et al. The Mother's autonomy in decision making (MADM) scale: patient-led development and psychometric testing of a new instrument to evaluate experience of maternity care. PLoS One. 2017;12(2):e0171804. doi:10.1371/ journal.pone.0171804.

20. Vedam S, Stoll K, Rubashkin N, Martin K, Miller-Vedam Z, Hayes-Klein H, et al. The mothers on respect (MOR) index: measuring quality, safety, and human rights in childbirth. . Social science and medicine. PopulHealth. 2017; In press, January 2017

21. Baji P, Pavlova M, Gulacsi L, Groot W. Exploring consumers' attitudes towards informal patient payments using the combined method of cluster and multinomial regression analysis the case of Hungary. BMC Health Serv Res. 2013;13:62. doi:10.1186/1472-6963-13-62.

22. Szende A, Culyer AJ. The inequity of informal payments for health care: the case of Hungary. Health Policy. 2006;75(3):262-71.

23. Gaal P, McKee M. Informal payments for health care and the theory of INXIT. Int J Health Plann Manag. 2004;19(2):163-78.

24. Stepurko T, Pavlova M, Gryga I, Groot W. Empirical studies on informal patient payments for health care services: a systematic and critical review of research methods and instruments. BMC Health Serv Res. 2010;19(10):273.

25. Slocumb E, Cole FL. A practical approach to content validation. Appl Nurs Res. 1991:4(4):192-5.

26. Lynn MR. Determination and quantification of content validity. Nurs Res. 1986;35(6):382-5.

27. Schilling LS, Dixon J, Knafl K, Grey M, Ives B, Lynn MR. Determining content validity of a self-report instrument for adolescents using a heterogeneous expert panel. Nurs Res. 2007;56(5):361-6.

28. Adler NE, Stewart J. Using team science to address health disparities: MacArthur network as case example. Ann N Y Acad Sci. 2010;1186:252-60.

29. Sandall J, Soltani H, Gates S, Shennan A, Devane D. Midwife-led continuity models versus other models of care for childbearing women. Cochrane Database of Syst Rev. 2016;4:CD004667. doi:10.1002/14651858.CD004667. pub5.

30. Saito S, Nomura N, Noguchi Y, Tezuka I. Translatability of family concepts into the Japanese culture: using the family environment scale. Fam Process. 1996;35(2):239-57.

31. Braun V, Clarke V. Using thematic analysis in psychology. Qual Res Psychol. 2006;3(2):77-101.

32. Frank L, Forsythe L, Ellis L, Schrandt S, Sheridan S, Gerson J, et al. Conceptual and practical foundations of patient engagement in research at the patient-centered outcomes research institute. Qual Life Res. 2015;24(5): 1033-41.

33. Baji P, Rubashkin N, Szebik I, Stoll K, Vedam S. Informal cash payments for birth in Hungary: are women paying to secure a known provider, respect, or quality of care? Soc Sci Med. 2017;189:86-95.

\section{Submit your next manuscript to BioMed Central and we will help you at every step:}

- We accept pre-submission inquiries

- Our selector tool helps you to find the most relevant journal

- We provide round the clock customer support

- Convenient online submission

- Thorough peer review

- Inclusion in PubMed and all major indexing services

- Maximum visibility for your research

Submit your manuscript at www.biomedcentral.com/submit

) Biomed Central 